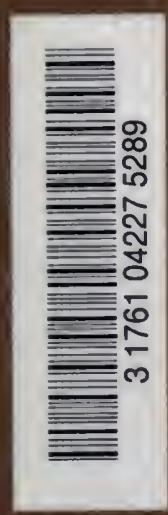

I 4 087 1900

c. 1 ROBA 



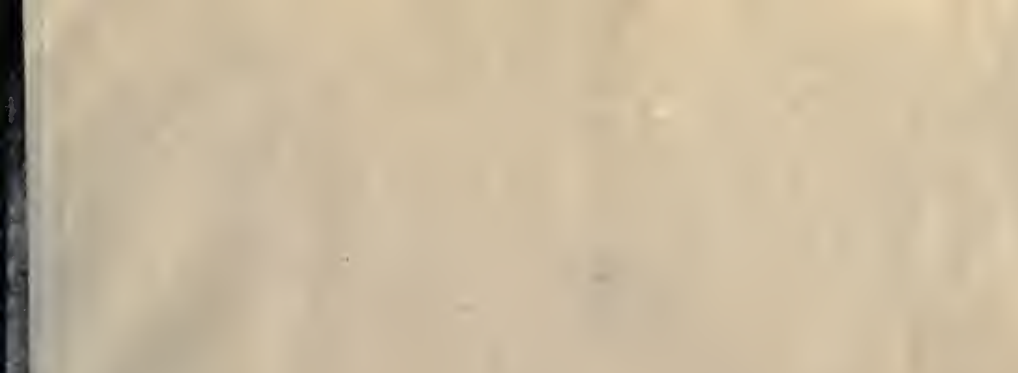




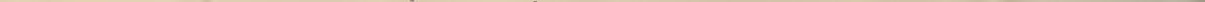


$=$ 



\section{GOVERNMENT OF INDIA}

\section{DEPARTMENT OF AGRICULTURI}

\section{OUTLINE OF AN AGRICULTURAL PLAN}

POR $\triangle N$ AVMRAQR PBOVINOM

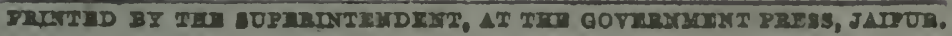


<smiles></smiles> 


\section{PREFACE}

THIS memorandum is meant solely for the use of officers who are called upon to put up schemes for growing more food or for inclusion in the plan of the post-war development of Agriculture. Under the term Agriculture are included not only Crop Production but also Horticulture, Animal Husbandry, Fisheries, Forestry and Cooperation.

The general lines along which plans have to be prepared are now well recognised. Land has to be reclaimed and developed, water, manure and seed have to be provided, pcsts and diseases have to be guarded against, the production of milk and fish have to be increased, village fuel plantations have to be set up, multi-purpose cooperative societies organised and so on. But these general ideas have to be translated into concrete and specific schemes. Naturally the precise schemes to be taken up will vary from Province to Province and the type of work envisaged in each scheme will also have to vary with local conditions. But it is felt that some guidance on these points may be helpful.

Accordingly, this memorandum gives in outline the nature of the scheme to be included under each major head of the plan. Some of these schemes may be unsuitable for some areas; some schemes may have to be dropped because they are beyond the resources of the Province concerned. But the outline may provide a list from which to pick and choose.

In addition, type schemes for a large number of sub-heads are appended. They are designed mainly to give an indication as to the lines on which such schemes should be prepared and the sort of information that should be given therein. The figures given are merely for illustration and will vary according to local conditions. The type schemes as such will therefore not be suitable for any area; but it is hopea that they will help the officers concerned for preparing schemes suited to their own conditions.

The memorandum has been prepared jointly by a number of different officers in the Central Department of Agriculture. 
Digitized by the Internet Archive in 2007 with funding from Microsoft Corporation 


\section{GENERAL OBSERVATIONS}

1. The aim of a plan of Agricultural development is to increase production, improve efficiency and enhance the net income of the producer, so as to improve his standard of living. Hence the plan must clearly indicate the extent to which it will help in attaining this aim.

2. In other words it is not enough to have a collection of isolated schemes however excellent and necessary they may be. Each of these schemes must indicate the extent to which it will further the general plan and it must also be stated as to what the cumulative effect of all these schemes when integrated together will be for the province as a whole. Each scheme must show how and to what extent it will increase production and the plan must show the total extent to which production will be increased as a result of the various schemes in each year, so that it may be seen what the total increased production is likely to be in a specified period.

3. It follows that the appointment of extra staff is not an end in itself; it is but the means by which the various schemes can be put into effect. Hence the staff must be correlated to the scheme of work. Proposals for increase of staff must indicate clearly how and to what extent such increase will help directly or indirectly in increasing production.

4. For the proper framing of a plan, a good deal of preliminary or preparatory work is essential. It is necessary in the first place to make enquiries and ascertain the requirements in the shape of works, goods and services. For instance, before deciding how many wells to construct, it has to be ascertained by enquiries from tract to tract how many wells are needed in each area and what the scope is for the construction of such wells. Next, the availabilities of material, staff etc.' for such construction have to be looked into. Thereafter it can be indicated that so many wells can be constructed at once and so many more after such and such material or staff can become available. The plan should also provide for obtaining the requisite goods and training the staff required. The total increased production expected from the wells must also be mentioned.

5. It is not suggested that work should be held up while such enquirics are going on. The construction of works can and should go on in so far as this can be done with the available material and stafi and steps sliould be taken forthwith to construct such works as are 
known to be required. But the necessity for detailed investigations for the drawing up of a proper plan must not be lost sight of.

6. Again, in framing a plan it is advisable to avoid a diffusion: of activities by taking up too many small items. The available resources in men and materials should be concentrated on schemos which will give the maximum production in the shortest time at the least cost per unit of production, the aim being to produce a specific quantity of more food or other agricultural commodity in a specific time.

7. For this purpose, special attention has to be paid to schemes of development or the application of results of research. Research is undoubtedly essential and adequate provision must be made for it. But at the pr usent stage experiment is perhaps of greater practical value i.e. the taking over of the results of research already carried out in the province or elsewhere and trying them out under local conditions of soil and climate. Such experimentation is an essential preliminary to the giving of sound advice to cultivators as to how to increase production under their conditions.

8. This has to be followed up by schemes designed to make the necessary facilities in the shape of works, goods and services, available to cultivators at a cost which is within their means so that they may be able to take up the activities which are considered suitable from the point of view of increasing production.

9. It is in the light of these conditions that the following suggestions are offered as regards the types of schemes that may best be included in the provincial post-war development plans. It is realised that when the provincial plans were prepared, the need for concentrating attention on increased production had not perhaps been fully realised. The suggestions now offered may mean a certain amount of increased work for the Departments concerned. The only object however is to help each province to make the best use of the funds available to it in the mutual intcrests of all.

10. It has to be emphasised that the carrying out of the plan will nood the full cooperation of the departmental staff with the agriculturists and the latter must be suitably organised for the purpose.

11. It may perhaps again be made clear that the type of schem $3 \mathrm{~s}$ appended to this memorandum are not intended to apply to any provincs. They have been drawn up on a purely hypothetical basis and are intended to serve as specimens for the framing of provincial schemes, The type schemes will have to be modified 
to suit the local conditions of the province, including in some cases the combination of different schemes into a single unitary scheme or vice versa. It is however necessary that all the relevant facts should be presented in the bluc prints of the schemes; that the objectives and the methods by which it is proposed to attain them should be clearly indicated; and that the probable increased production should be mentioned. The Central Department of Agriculture will be glad to render any assistance that a province may require for the preparation of its detailed schemes. 


\section{OUTLINE OF AN AGRICULTURAL PLAN FOR AN AVERAGE PROVINCE}

The plan for the development of Agriculture in the Province aims at securing increased production and improving the efficiency of agricultural operations, so as to increase the net income of primary producers. For this purpose it is proposed to make the requisite facilities, in the shape of works, goods and services, available to them, at a cost which is within their means, and to organise the primary producers to enable them to take advantage of the same.

2. The province has 5 divisions, 25 districts, 100 tehsils, 500 firkas or assessment circles, 2000 zails or union boards and 50,000 villages. Its total area is 50 million acres, so that the average size of a village is 1000 acres. A zail has 25 villages, a firka has 100 villages, a tehsil has 500 villages and a district 2000 villages.

\section{PLANT HUSBANDRY}

3. Out of the total area of 50 million acres in the Province, $6 \frac{1}{2}$ million acres are under forest, while $8 \frac{1}{2}$ million acres are classed as not available for cultivation. Out of the remaining 35 million acres, 10 million acres are shown as culturable waste, 5 million acres as current fallow and 20 million acres is the net area sown. The do-fasli area is $3 \frac{1}{2}$ million acres so that the total area sown is $23 \frac{1}{2}$ million acres.

4. The main items included in the programme of increased crop production are (1) improving minor irrigation facilities by helping in the construction of surface percolation wells, tube wells, pumping installations tanks, channels etc., (2) carrying out other minor works of land improvement and development especially for the conservation of moisture and the prevention of erosion, (3) bringing culturable waste and fallow land under cultivation, (4) supplying manures and fertilisers at subsidised rates, (5) multiplying and distributing improved varieties of seed, (6) protecting crops from pests and diseases, (7) supplying iron, steel and agricultural implements including in some cases tractors, (8) adopting improved cultural practices such as the right time of sowing, the correct seed rate, transplanting where required instead of broadcasting etc., (9) developing vegetable and fruit growing, (10) providing advisory services for extension work and (11) carrying out research.

5. Land Development Works. - In order to increase the area under cultivation and obtain higher yields per acre, it is necessary to construct a number of minor works for the development of the land. Both the intensive and the extensive system will be adopted for the purpose. 
For intensive work in a particular area, a suitable block of land such as a watershed will be selected. A project will be prepared for this area, indicating all the works of land development that are needed for the reclamation of the land and the measures that have to be taken for securing its best utilisation. This is known as the project method.

It is not however proposed to wait for the results of such enquiries before taking action. For most areas it is known roughly what types of works are needed. A separate scheme is put up for each type of work to be constructed. These works are dealt with below under two main heads viz. (1) Irrigation Works and (2) Soil Conservation or other Works.

6. Irrigation Works.-The present position in respect of irrigation is that only some $5 \frac{1}{2}$ million acres are irrigatcd -3 million acres from canals, $1 \frac{1}{2}$ million acres from wells and one million acres from tanks.

The extension of the canal system is primarily a matter for the Irrigation Department but the agricultural staff will be closely associated with these proposals.

Tube wells will be constructed at.....places and the scope for the construction of more tube wells will be ascertained by trial borings (Scheme 1.1.)

Help will be given to agriculturists for the construction and equipment (with Persian Wheels) of......new masonary surface wells and for the repair and improvement of.......existing wells (Scheme 1.2).

Similar work will be taken up in respect of tanks (Scheme 1.3).

Dams will be constructed at ....places on streams etc. so as to utilise the water so conserved for irrigation and provided with water lifting pumps (Schome 1.4).

It is hoped by these measures to increase the irrigated area from $5 \frac{1}{2}$ to...... million acres in the next five years and to increase the double cropped area from $3 \frac{1}{2}$ to..... million acres in the same period. This is likely to result in an increased production of ....tons a year.

7. Other minor works.-These include works for the conservation of soil and moisture and the prevention of erosion. They are best carried out in connection with the execution of projects for selected blocks of land. But, for some areas, certain types of work can be taken up independently of the projects. In particular, 
Forestation with contour trenching will be taken up in..... acres (Scheme 2.1).

Pastures grasses will be planted in .......acres (Scheme 2.2).

Contour bund will be constructed for the protection of..... acres from erosion (Scheme 2.3).

Agriculturists will be helped to construct field bunds (i.e. watt bunds or daul bunds) for the conservation of moisture in......acres (Scheme 2.4).

Embankments will be put up for......miles to prevent lands from being flooded by streams (Scheme 2.5). Larger works of this kind would primarily be the function of the Public Works Department.

Masonry check dams or brush dams will be constructed in ......places for gully plugging in order to prevent the extension of erosion (Scheme 2.6), and

To prevent water logging,......miles of drainage cuts will be constructed (Scheme 2.7).

By these means it is hoped to bring.....extra acres under cultivation,...... under grass and..... under trees.

8. Land Development Project.-Enquiries will be made in respect of each selected block of land such as a water-shed to ascertain what portions of the area which is not available for cultivation is fit for being put under fuel trees and grasses, how much of the culturable waste can be brought under cultivation and how much of it kept under trees and grasses, and what works and facilities should be provided for reclaiming these lands and putting them to the maximum use. Similar enquiries will be made as to the works and facilities needed in the cultivated areas for improving the efficiency of cultivation. A. Land Development Organisation will be set up for guiding and directing this work (Scheme 3.1).

The actual preparation of projects will be carried out by special staff dealing with a selected block of land. This staff will ascertain (where necessary) the nature of the soil, collect the requisite data, put forward suggestions for works to be undertaken and indicate roughly what goods, equipment and staff are required for the purpose (Scheme 3.2). 
As soon as possible after a project for a block of land has been prepared, steps will be taken to put it into effect by carrying out the necessary works and measures. This will entail a great deal of propaganda and some legislation, till people are convinced of the wisdom of the measures suggested. Some portions of the projects will be carried out by the cultivators themselves, with the help of the normal departmental staff; other portions will require special staff.

9. Manures.-In order further to increase production, steps will be taken to popularise the better preservation and greater use of manures and fertilisers specially in irrigated tracts.

Farm and village refuse.-Farmers will be encouraged and helped to preserve farmyard manure and village refuse in compost pits; it is hoped to increase the present production of manure in villages by about 6 million tons during the next five years (Scheme 4.1).

As an experimental measure, compost "factories" will be started in selected villages. The refuse will be made over to special staff who will arrange for proper composting and will hand over a proportionate quantity of ripe manure to each individual concerned in due course. This will it is hoped serve to stimulate increased compost manufacture and show to farmers the best methods to be adopted. It is proposed to establish 1000 such "factories" in the Province (Scheme 4.2).

The preparation of compost from town refuse will be taken up at all the towns in the province with a population of 5,000 or more and it is hoped to produce 400,000 tons of manure from this source. Adequate steps will be taken to ensure rapid distribution of this manure by subsidising its transport and use (Scheme 4.3).

The Sewage and Sludge, available at the bigger municipal centres, will be utilised for increasing agricultural production, under safeguards so as to ensure hygienic conditions. Fodder crops, sugarcane and fruit trees will be generally grown under sewage (Scheme 4.4).

Slaughter house wastes, which are now being buried, will be converted into useful manure such as dried blood and offal-cake and subsidies will be offered to popularise their use among cultivators (Scheme.4.5).

Arrangements will be made for the collection of bones (estimated at.....tons) and their utilisation as manure in the form of bonemeal or bone-char (Scheme 4.6). 
Efforts will be made to ensure that every acre of irrigated land is green manured at least once every five years and arrangements made for the supply of the neccssary seed (Scheme 4.7).,

Fertilizers and Oil-cakes.-Chemical fertilizers and oil-cake will be supplied at subsidised ratcs for....... acres in the first year working up to.......acres in the fifth yoar (Scheme 4.3).

The extension staff will give advice to farmers as to the best time of application and the type and quantity of manure to be used, bearing in mind the nature of the land. They will have manurial tables with them for the purpose.

As a result of these measures, it is hoped to increase production by......tons a year and build up soil fertility.

10. Seed.-With the greater use of water and manure, the use of better seed will give higher production. Improved seed is however available only in respect of wheat, paddy and cotton. The aim is to place half the area under each of these crops under pure improved seed in the course of 4 years and to koep on renewing the seed every year to prevent deterioration.

For this purpose it is proposed to produce pure nucleus seed at the Government seed farm. For purposes of multiplication, this seed will be given to A grade growers, their produce bought and stored and given out the following year to B grade growers whose produce will be similarly bought and stored. The necessary number of seed stores will be set up. The seed from these stores will be given out to cooperative or other suitable agencies for further distribution; these agencies will have to comply with certain conditions and will be given concessions especially in respect of the construction of stores (Scheme 5).

It is anticipated that the annual increased production from the use of improved seed will be......tons.

11. Plant Protection. - Control measures will be adopted against pests and diseases e.g. removing stubbles, burning trash etc. Insecticides and fungicides will be made available to farmers on a subsidised basis. Spraying and dusting machinery will be given out on hire or sold at subsidised rates. Advice will be given to farmers and orchard owners as to the exact measures they should adopt in each caso (Schemo 6).

12. Implements.-Iron and steol for the manufacture of agricultural tools by village blacksmiths will be obtained in bulk and made available to agriculturists (Scheme 7.1). 
Improved implements up to $20 \%$ of the total estimated demand in the province will be obtained, partly by manufacture in a Central Workshop and partly by purchase from the trade, and distributed throughout the province at subsidised rates or on hire to cultivators in order to popularise them (Scheme 7.2).

In selected areas power farming units consisting of tractors and tractor drawn equipment suited to local conditions will be set up and utilised for helping to bring culturable waste land under cultivation They will either work on a contract basis or be given out on hire (or if necessary free of charge) for carrying out agricultural operations for which adequate bullock power is not available in time (Scheme 7.3).

13. Depots.-Stores or depots will be established from where agricultural implements can be either sold if necessary on a subsidised basis or hired out to farmers as may be considered appropriate. These depots will also stock and supply fertilisers and will be run along with seed stores (Scheme 8).

14. Cultural Practices.-The cultural practices which will result in high production will vary from block to block according to the nature of the soil and climate. The province will be divided into..... blocks on the basis of soil climate differences.

An experimental farm will be established for each such block and also in every large area where irrigation will be newly introduced. At each of these farms, suitably planned and designed experiments will be laid down. Their objective is to ascertain as quickly as possible the relative merits and suitability for the block :-

(a) of the different crops grown, bearing in mind the need for rotation,

(b) of the different varieties of seed for each of these crops,

(c) of the different types of manures required for these crops, of their differing doses alone and in combination with each other and of their economics relative to the prices of the crops manured,

(d) of the amounts and periodicity of irrigation, and

(e) of the other cultural practices to be adopted $\theta . g$. the seed rate to be used, the optimum time for sowing, the need for weeding, transplanting etc., the use of the right type of implements and so on (Scheme 9.1). 
The results obtained at thesc farms will then be tried out on trial plots belonging to landlords or selected cultivators under their own conditions (Scheme 9.2).

If the results are found to be satisfactory, field demonstrations will be given on a large scale on the fields of cultivations (Scheme 9.3).

15. Vegetables:-The existing production of vegetables needs to be increased $2 \frac{1}{2}$ times to meot the nutritive needs' of the population. ISteps will therefore be taken to increase the acreage under vegetables and to supply seed for vegetables at subsidised rates in the beginning (Scheme 10.1).

Arrangements will be made for the production of potato seed and its maintenance in cold stores to prevent deterioration (Scheme 10.2) and where this is not feasible for the transport of the type of potato seed needed for each block from the area producing the same (Scheme 10.3).

16. Fruits.-In order to improve fruit eulture, it is necessary to select bud wood of the right type; existing orchards will be surveyed tơ :äscertain the kinds and varieties of trees growing successfunty in each orchard and to locate trees of outstanding merit (Scheme 11:. $)$.

These selected trees will be utilised for propagating nursery plants and Government nurseries will be set up for producing'and distributing plants of good varieties (Scheme 11.2).

Experimental orchards will be set up to ascertain the best varieties to be used and the best methods of cultivation to be adopted for each block (Scheme 11.3).

Along with them commercial orchards will be established to serve as demonstrations or models; they will in course of time supply good quality bud wood (Scheme 11.4).

Fruit growers will be helped to set up new orchards in...... acres and to renovate...... acres of existing orchards by top working or otherwise (Scheme 11.5).

The training of malis will be taken up on practical lines so as to make malis available for fruit growers who wish their orchards to be properly looked after (Scheme 11.6).

A Fruit Development Board or Fruit Growers Association will be set up which will encourage the adoption of better methods of horticulture and hold fruit shows for the purpose (Scheme 11.7). 
A Fruit Technological Laboratory will be set up where, experimental work will be taken up in the preservation of local fruits and vegetables. This will also be used for testing the quality of fruit products produced by the industry and will help them in solving their problems (Scheme 11.8).

Short courses will be arranged in home preservation of fruits for consumption in the home (Scheme 11.9).

1\%. Crop Planning.-It will not be feasible to take up crop planning as such. But every effort will be made to increase, the acreage under selected crops. The present position is that out of $23 \frac{1}{2}$ million acres sown, 18 million are occupied by foodgrains including 7 million acres under rice, 3 million under wheat, 7 million under millets and one million under pulses. Fibres cover 2 million acres and oilseeds another $1 \frac{1}{2}$ million acres. The remaining 2 million acres are shared equally by sugarcane, fruits and vegetables, fodder crops and miscelianeous crops, each of them covering half a milliop acres approximately.

It is proposed to increase the acreage under rice and under oilseeds by $\frac{3}{4}$ million acres each, and under wheat, under fruits and vegetables and under fodder crops by half a million acress each."

The land for this increase of 3 million acres will become available partly from the additional area that will be brought under cultivation and irrigation, and partly from an increase in the couble cropped area. Some land will also become available when the yields of nonfood crops increase and their acreage can therefore be reduced without decreasing their production.

18. Extension. - In order to carry out all this work it will be necessary to maintain a proper organisation and extension staff. As there are 25 districts, 100 tahsils and 500 firkas in the Province, the district staff will consist of 2,000 Kamdars, 500 Fieldmen or Supervisors (, non-graduates), 100 Inspectors (graduates) and 25 Superintendents (gazetted Class II) and 5 Deputy Directors. Taking into consideration the existing staff, the extra staff required is........ (Scheme 12). This staff will be in addition to the special stiff that will be required for items such as seed farms, experimental farms, depots, etc. There will also be Inspectors and Superinterdents etc. for work in connection with horticulture plant protection and agricultural engineering.

19. Research.-The provincial research farm will i.e expanded. Research in Axronomy (cultural practices) will be intensified. Pl?nt breeding work will be carried on, in cooperation with the different 
commodity committees, institutes or the I.C.A.R., for ovolving and trying out new varieties there will be a separate scheme for each crop, e.g. for rice, wheat, millets, pulses, oilseeds, cotton, jute, sugarcane, tobacco etc. Research will also be increased in respect of Plant Chemistry and Soil Science, Plant Physiology, Entomology, Mycology and other plant diseases, Horticulture and Agricultural Engineering (Scheme 13).

20. Hexdquarters. - The additional staff required to help the Director will be....... officers. The ministerial and menial staff will also have to be enhanced. The office accommodation will have to be increased (Scheme 14).

21. Total Staff.-A statement is appended showing the number of persons of each category that will be required in each of the 5 years starting from 1947-48.

22. Training.-Arrangements will be made for the training of Kamdars at farms (Schome 15.1), of mates for agricultural engineering (Scheme 15.2), of fieldmen, supervisors or non-graduate assistants (Scheme 15.3), of overseers or non-graduate engineering assistants (Scheme 15.4), of Inspectors or graduate assistants (Scheme 15.5), of gazetted staff for post-graduate training in India (Scheme 15.6) and of higher gazetted staff for post-graduate training abroad (Scheme 15.7).

23. Increased Production. - The total increased production expected as a result of all these measures, given proper advice and guidance by the staff, from the 5 th year onwards is 800,000 tons a year. The non-recurring cost involved is Rs......lakhs; while the annual recurring expenditure from the 5th year onwards will be of the order of Rs.......lakhs, apart from loan money to the extent of Rs........lakhs.

\section{ANIMAL HUSBANDRY.}

24. The cattle population of the province consists of 5 million bullocks, 4 million cows, 3 million young stock and 2 million buffaloes. In addition there are 3 million sheep, 4 million goats and 5 million poultry.

25. Disease Control.-There are at present 20 veterinary hospitals (where inpatients are received), and ...........fixed dispensaries in addition to........ field dispensaries and........ first aid centres.

It is proposed to convert....... dispcrsaries into hospitals so as to incruase facilities fcr tratment (Scheme 16,1). 
Further,.......extra dispensaries will be constructed, from which it will be feasible to look after..........additional field dispensaries which will serve firke or thana headquarters. (Selhemo 16.2).

In addition it is advisable to have a first aid centre at the headquarters of each stockman i.e. at 2000 places (Scheme 16.3).

Steps will be taken to provincialise hospitals, dispensaries etc. so that difficultios of dual control may be reduced (Scheme 16.4).

All the cattle in the province will be inoculated free of cost to secure immunization against rinderpest. Compensation will be paid if an animal dies as a result of such inoculation, to the extent of half its value (Scheme 16.5).

The regular staff will also carry out inoculation against other contagious diseases e.g. tuberculosis, contagious abortion etc. (Scheme 16.6) and take measures against parasitic diseases e.g. cattle dips against ticks, (Scheme 16.7), the use of derris powder against warbles (Scheme 16.8) etc.

To prevent the ingress of diseased animals and inocluate those which come in........quarantine stations will be established (Scheme 16.9).

To meet the requirements of sera and vaccine their production will bo increased (Scheme 16.10).

23. Feeding.-Advice as to the most suitable cattle feed for (ach locality, based on what is available locally, will be given to cattle owners by the extension staff.

Arrangements will be made for the supply of concentrates on a subsidised basis to si cure their equitable distribution (Scheme 17.1).

The equirements of green fodder will be mot by increasing jroduction along the lines indicated in para 17 and fodder trees will ke planted along with fuel plantations. The chaffing of green fodder will be popularised (Scheme 17.2).

The conservation of fodder by making hay and sileage will be encouraged (Schems 17.3).

Grizing lands will be improved by the introduction of rotat onal grazing and reseeding where necessary (Scheme 17.4).

27. Breeding. - The cattle which are mostly nondescript will be gra ocd up by the use of improved bulls. This is a long term 
programme and will be worked throughkoy villages instead of establishing a large number of government farms.

There will be a government bull breeding farm for each division, depending on the breed it is proposed to propagate most in the division. Thus it will be posssible to have a separate farm for bulls required for draught purposes, for bulls required for milk and for buffalo bulls.

The bulls produced at the divisional farm will be given out to selected or key villages and entrusted to darindas. The male offspring of the bulls from key villages will be supplied, when they are of age, to other villages in the vicinity. Thus stud bulls will be maintained in all villages and the whole of the village stock will be graded up in the course of......... years. The organisation so set up will maintain a supply of better and still better bulls from generation to generation (Scheme 18.1).

This work will have to be supplemented by legislation to secure the castration or removal of all other bulls.

Where this system of work is not feasible, cooperative cattle breeding societies will be set up (Scheme 18.2).

Artificial insemination will be introduced wherevor practicable ; this will reduce the number of bulls that will have to be maintained (Schemo 18.3).

Action will be taken on similar lines for the breeding of better sheep for improving the wood produced, for breeding goats, for the breeding of poultry and the production of eggs and for breeding other forms of livestock (e.g. horses, mules, donkeys, camels, pigs etc.)

28. Dairying. - The present production of milk in the province is only 1.5 million tons a year. This comes on an average to $1 \frac{1}{4} \mathrm{lbs}$ a day per cow and $2 \mathrm{lbs}$ per day for a buffalo or double these amounts if only animals in milk are considered. Milk production will be increased with the better foeding and breeding of the cattle, including the supply of tested bulls. But further action is called for in order to increase production to 2 million tons in five years.

Accordingly steps will be taken to secure the increased production of green fodder in villages (Scheme 19.1). At the same time it will be necessary to assure to the producers a remunerative market for their milk. Care will however be taken to ensure that villagers are left with some milk for their own consumption.. Further action for the proper maintenance of their animals e.g. shortening the dry period, will be taken by the cattle owners themselves, 
In the areas near each important town a survey will be made of the production of milk and the scope for increasing the same as well as of the consumption and utilisation of the milk. This will provide data for a comprehensive scheme of work (Scheme 19.2).

Arrangements will then be made for the supply of milk from the rural areas to the towns. Cattlo owners will be organised cooperatively for milk production and milk recording. A Milk Union will be set up which will collect the milk from the producing areas, arrange for its transport, process it and distribute it, providing the necessary refrigeration and cold storage arrangements (Scheme 19.3).

This will be supplemented by arrangements for the supply of clean water in villages where necessary (Scheme 19.4).

Dairy farms will be set up for the production of both milk and bulls; cows and buffaloes will be maintained on green fodder grown at the farm, the dry fodder requirod being purchased from the neighbourhood (Scheme 19.5).

Farms will also be established for the salvage of dry stock from cities and the rearing of young animals (Scheme 19.6).

Rúral creameries will be established for making butter, milk powder $\theta t c$. in areas where the milk cannot be utilised as fluid milk; this will secure the proper utilisation of the milk produced, prevent wastage and enable the producers to get better value for it (Scheme 19.7).

The village methods of manufacturing ghee will be replaced by cream separators in selected places; this will give a higher out-turn of ghee and have the skim milk for the use of villagers (Scheme 19.7).

Apart from the staff required for the individual schemes mentioned above, special staff will be appointed specifically for helping in dairy development (Scheme 19.9).

29. Gaushalas.-Steps will be taken for the reorganisation and improvement of Gaushalas so that they may take up the production of more milk, the breeding of cattle on scientific lines and the salvage of dry cattle. For this purpose land will be placed at their disposal for grazing cattle, and for growing fodder. They will be supplied on suitable terms with pure bred cows and bulls and helped to put up cattle sheds and dairy equipment (Scheme 20). 
30. By-Products. - The utilisation of the by-products of animal slaughter will also be attended to and the existing slaughter houses improved (Scheme 21).

31. Extension.-The extension staff will consist of 2,000 stockmen, 500 livestock supervisors, 100 livestock Inspectors, 25 livestock superintendents and 5 deputy directors, less such staff as can be dispensed with owing to the presence of veterinary assistant surgeons. The necessary buildings for laboratories, officers etc. will also have to be provided along with the requisite ministerial and menial staff (Scheme 22.1).

Education in the proper management of livestock will also be arranged for by means of leaflets, cinema films etc. and by the organisation of livestock shows (Scheme 22.2).

32. Research.-There will be a provincial livestock research and experiment farm where work will be carried out on animal genetics and nutrition (Scheme 23.1). In addition there will bc special research officers for studying the diseases of cattle, sheep, and goats, poultry etc. with the necessary laboratory and office accommodation and the requisite ministerial and menial staff (Scheme 23.2).

33. Headquarters. - The staff at headquarters will also need to be strengthened to deal effectively with the various increased activities, along with the necessary laboratory and office accommodation and the requisite ministerial and menial staff (Scheme 24).

34. Training.-A statement is appended showing the total extra staff of different categories required in each of the next five years. The training of stockmen, compounders, dressers etc. will be arranged for in the requisite number (Scheme 25.1).

Selection will be made of suitable persons for training as veterinary, livestock, dairy assistants etc. and they will be trained at the Provincial Animal Husbandry College : the facilities for training there will be considerably increased for the purpose (Scheme 25.2). In the alternative the persons selected will be sent to colleges in neighbouring provinces for training (Scheme 25.3).

The requisite number of gazetted officers will be trained at the I. V. R. I. (Scheme 25.4) and the higher staff needed sent for training abroad (Scheme 25.5).

35. Increased Production.-The increased production expected from tho valious measures adopted and the action taken by the staff 
from the 5 th year onwards is......... The non-recurring cost involved is $\mathrm{Rs} . . . .$. . lakhs, while, the annual recurring expenditure from the fifth year onwards will be of the order of Rs........ lakhs apart from loen money to the extent of Rs....... lakhs.

\section{FISHERIES.}

36. The present production of fish from rivers, lakes, jhils, tanks and ponds is 6 lakh maunds a year and from marine waters 2 lakh maunds a year. The plan provides for the increase of these figures to...... and....... maunds respectively.

37. Inland Fisheries.-A survey will be made of the spawning grounds of the types of fish required for stocking tanks and ponds (Scheme 26.1).

The spawn will becollected and hatcheries and nurseries set up for the raising of fry. These fry will be reared into fingerlings in conditioning ponds, where such a course is necessary. The fry or the fingerlings as the case may be will be taken to the selected ponds and tanks for stocking. These tanks will usually have to be cleaned and deepened before they are stocked and in some cases manured as well. Proper arrangements will also be made to ensure that fishing is not resorted to before maturity (Scheme 26.2).

38. Marine Fisheries.-It has not been feasible to work out the proposals in respect of marine fish in detail because of lack of experience and staff. The work of introducing power boats and gear will be taken up on an experimental basis.

At the same time a number of better sailing boats will bo constructed and supplied on a subsidised basis (Scheme 27.2).

Carrier launches will be arranged for, adequately equipped with ice to bring the catch from the fishing boats, harbour facilities improved (e.g. landing jetties provided) and arrangements made for transport (Scheme 27.3).

The existing fish curing yards will be improved and......new curing yards established where modern facilities will be provided to fishermen (Scheme 27.4).

39. Supply Depots.-Steps will also be taken for the supply to fishermen of the necessary facilities in the shape of the materials required for making nets maintaining boats, fishing hooks etc. by setting up cooperative depots for the purpose (Scheme 28).

40. Staff.-The staff for fisheries work is inadequate and will be enhanced (Scheme 29). 
41. Training.-Fishery schools will be set up near the larger ports, for turning out men who would later become captains of fishing craft or hold subordinate positions in the fishing industry (Schome $30.1)$.

Arrangements will also be made for higher training for the staff by giving stipends and scholarships for training at the appropriate seation of the Central Fisheries Institute (Scheme 30.2).

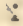

(1)

\section{COOPERATION.}

42. There are in the province.......cooperative credit societies and ....... societies of other types. Aspects of cooperative work other than credit need to be developed especially the marketing side. Each village will be suitably organised so as to secure full cooperation betwoon the villagers and the staff.

43. Multi-purpose Societies.-It is proposed to convert the existing credit societies into multi-purpose societies and to organise .......now multi-purpose societies. These societies will notonly supply credit, but take the lead in introducing improvements, in supplying the noeds of the villagers and in bettering village conditions (Scheme 31).

44. Marketing Societies.-For every 100 multi-purpose-societios, there will be one marketing society situated at a mandi or fiika headquarters. It will arrange for the cleaning, grading and bulking of the produce, either directly or through its affiliated village societies and will maintain a warehouse or godown. It will be provided that where a majority of the villagers wish to market their grain through the society, it will be binding on all the villagers to do so. There will be a grain marketing union at each district headquarters with its own warehouse and a grain marketing federation for the province. These will be linked up with consumers cooperative societies where feasible (Scheme 32 ).

45. Other special societies.-Cooperative societies for the consolidation of holdings at present number......... In order to expedite the work, the staff for the purpose will be increased so that at least.........additional villages may be consolidated each year (Scheme 33.1).

Cooperative farming will be taken up in selected villages and particularly in areas which are newly devoloped (Scheme 33.2).

Cooperative societies will be established for cottage industries with a central organisation to assist in the sale of the finished articles (Scheme 33.3). 
46. Staff. - The staff of the Cooperatite' Department will be increased to enáble it to cope offectively with the additional activities it will take up, especially in respect of marketing (Scheme 34,1 ).

Arrangements will also be made for the training of the staff required (Schemie 34.2).

\section{MARKETING.}

47. Measures will be adopted for the use and enforcement of regulated markets (Sclieme 35.2).

A separate Marketing Department will be set up under a Director of Marketing with the requisite staff, office accommodation etc. (Scheme 35.3).

\section{STATISTICS.}

48. The random sampling method will be introduced for ascertaining crop yields (Scheme 36.1).

Arrangements will be made for the correct estimation of the acreage under the different crops, in areas where the patwari organisation does not exist (Scheme 36.2).

The office of the Director of Land Records will be expanded so as to become a Directorate of Agricultural Statistics (Scheme 36.3).

\section{GENERAL.}

49. A suitable area like a Zail (25 villages) or a Firka (100 villages) will be selected where all known agricultural improvements will be taken up on an intensive scale. One such project will be started in each division (Scheme 37).

50. The plan outlined above must not be regarded as static; it has to be flexible and must be revised from time to time as required. In practice, it may be found necessary to drop some of the schemes suggested, on account of lack of men, money or materials or to modify them considerably. It may equally be necessary, in the light of experience, to add some other schemes, for the proposals put forward are by no means comprehensive.

51. Furtler, the economic aspect has not been touched on in this plan. For instance, cattle and crop insurance need further working out before they can be adopted under local conditions. Matters connected with the land tenure system with special reference 
to its effect on agricultural production are being looked into separately: The socuring of an assured market for agricultural produce at a remunerative price is an all India problem and will figure in a separate. plan for the province. Again, the agricultural plan must be integrated with the other development activities particularly those in respect of health, education etc. The present proposals are, in short, only: a part of a larger provincial plan. 



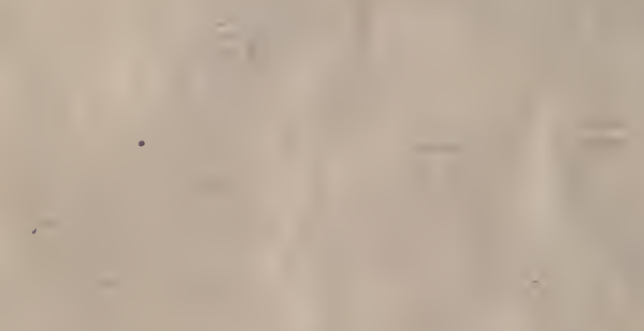




$$
7 \cdot
$$

\section{n}

เ 